\title{
Honor Crime in Sanaa Shalan's Tale of Tales
}

\author{
Saif AL Deen Lutfi Ali AL Ghammaz \\ Faculty of Social Sciences and Humanities, Universiti Kebangsaan Malaysia \\ 43600 UKM Bangi, Selangor, Malaysia \\ Tel: 603-8921-6481Ｅ-mail: saif@ukm.edu.my \\ Ruzy Suliza Hashim \\ Faculty of Social Sciences and Humanities, Universiti Kebangsaan Malaysia \\ 43600 UKM Bangi, Selangor, Malaysia \\ Amrah Binti Abdulmajid \\ Faculty of Social Sciences and Humanities, Universiti Kebangsaan Malaysia \\ 43600 UKM Bangi, Selangor, Malaysia
}

Received: April 1, 2020 Accepted: April 14, 2020 Published: April 15, 2020

doi:10.5296/ijele.v8i2.16849 URL: https://doi.org/10.5296/ijele.v8i2.16849

\begin{abstract}
Honor crime is a heinous global phenomenon occurring in several Arab and Islamic societies with varying magnitudes from one country to another. The growing number of honor crime cases, mostly in developing countries such as Jordan, demands serious academic investigation not only because the lives of the victims are at stake, but also because the phenomenon is still gravely overlooked and unaddressed due to socio-cultural norms branding it as a social taboo. Recently, there has been increasing interest among Arab and Jordanian writers in portraying honor killings against Jordanian women through their literary works (Fanous, 2018). Thus, in this paper, we shall examine the manifestations of honor crimes against women in the Jordanian context through a textual analysis of Tale of Tales by Sanaa Shalan, an author belonging to the Jordanian contemporary literary movement. Originally written in Arabic, this novella highlights the suffering of many Jordanian women due to honor crimes inflicted upon them by the poor and male-dominated society. Through an Islamic reading based on Quranic verses and Sunni Hadiths to read of Tale of Tales (2007), we shall examine Shalan's depictions of honor crimes against women in the novella as an extremely engendered phenomenon resulting from male domination and power and gender
\end{abstract}


inequity prevalent in the Jordanian society. This paper is premised based on two elements, namely: the misconception of honor and its association with the women's body and its roots in Islam, as depicted in Tale of Tales through the novella's female characters, notably the main protagonist.

Keywords: Family reputation, Islam, hadith, Sanaa Shalan, honor crime

\section{Introduction}

"In its report "Femicide: Understanding and Addressing Violence against Women," World Health Organization defines honor crimes as a "girl or woman being killed by a male or female family member for an actual or assumed sexual or behavioral transgression, including adultery, sexual intercourse or pregnancy outside marriage - or even for being raped" (WHO, 2012, p.2). Honor crime "is a widespread social problem in Arab and Islamic societies such as Jordan where gender inequality and male domination are the main traits of these societies, alongside a disparity of Islamic teachings' application in the lifestyles of the men and women" (Fanous, 2018, p.3). With the growing number of honor crimes in Jordan, international human rights organizations such as the Thomson Reuters Foundation and national human rights organizations such as the National Council for Family Affairs and Sisterhood Is Global Institute (SIGI, 2017) have ranked Jordan as the second worst Arab country in terms of the prevalence of honor crimes, with 50 female murders recorded annually from 2010 to 2018 (Hweija, 2016). Thus, the issue of honor crime is not a product of Shalan's imagination, but rather a truth clearly portrayed in the Tale of Tales on the realities of contemporary Jordan.

Historically, Jordanian women have suffered harshly from the oppression practiced by the male-dominated society. A husband may imagine that he is the ruler by God's command, and that in his view women are nothing more than a machine for reproductive purposes (Fayez, 2015). Therefore, Jordanian women suffer a complex oppression, especially after the outbreak of the new sectarian and ethnic conflicts which are far detached from Islamic teachings. Honor crime is an expected result of such social construction where it is committed under the pretext of "honor preservation" supposedly due to the immoral acts of a female in the tribe such as adultery, illicit relationships, or any other offenses against morality. In a patriarchal society, the honor of the family or tribe is related only to the women and their actions. While mistakes committed by the males are forgiven and forgotten, and even supported as depicted by the famous Jordanian proverb, "nothing disgraces man" (SIGI, 2017). As such, "it is not a surprise that the honor crimes are overlooked and ignored by Jordanian authorities, for it is a widespread social act supported by patriarchal domination over women" (Sharaf, 2018, p. 1).

With the intention of attaining a platform of empowerment to raise awareness among the Jordanian women concerning their rights and bridge the gap of gender inequalities between men and women, several literary figures especially those of the Jordanian contemporary movement such as Sanaa Shalan have used fiction to highlight the despair of Jordanian women. With the explicit aim to depict the miseries resulting from the act of honor crimes, Shalan, 
through Tale of Tales, has succeeded in doing so. Set in the south of Jordan, Tale of Tales revolves around the life of Amina who, being the only sister to her brother is left defenseless when her merciless brother decides to deprive her of her inheritance after their parents' death. The tension increases after Amina refuses to give away her inheritance and decides to marry the person of her choosing despite her brother's rejection. Out of spite, her brother decides that the only way for him to get what he wants is by killing Amina. He fabricates a story that Amina has an illicit affair outside of the folds of marriage and hence has tarnished the honor of the family and tribe. Amina is therefore sentenced to punishment by death whilst her brother is applauded as a hero by the society. Through her heroine, Shalan offers a harsh critique on honor crimes as a tragic practice suffered by many women due to the baseless social patriarchal practices prevalent in Jordan.

\section{Contextualizing Honor Crime}

In the Arab region, the term honor crime is used when a man kills a woman of his family or tribe due to suspicions of her having an affair or sexual relationship with a stranger. Honor crimes, however, are not motivated by jealousy or emotional reasons, but rather by social factors. As Haddad (2015, p. 3) argues, "the victims of these crimes are limited only to women because these families or tribes do not feel angry or disgraced, and may feel proud if the son or brother has an emotional or sexual relationship with a strange female because they consider the subject as an invasion of a family's entity." In these communities, women of other families and tribes are considered as the property and possessions of these tribes.

In patriarchal societies, males are applauded for pursuing their freedom whereas it is frowned upon for females to be independent in many aspects. Females are under intense scrutiny since young, and any misstep that is considered dishonorable to the family and society is punishable by death. "A patriarchal social construction encourages a man to control his family through force as a means of discipline" (Al Ghammaz, Ruzy Suliza Hashim, Amrah Abdulmajid, 2020, p.6). Thus, honor crimes are widespread in many Muslim and Arab countries such as Egypt, Iraq, Saudi Arabia, Syria, Yemen, Palestine, Pakistan, and especially Jordan. Khadr (2016) stated that honor killings in Jordan have increased, and more than 26 murders have been committed against women, mostly related to honor crimes, with $76 \%$ of the perpetrators being the husband or brother. In most of these countries, laws are enacted to protect the killers if they prove that their motive behind the crime was "honorable", which means that the closed tribal structure of these communities has led to this unjust treatment against women.

Yasin (2018) argued that the use of the term "honor crimes" to describe these killings is an indication of its acceptance and incitement by the society. The concept of honor linguistically means good qualities such as honesty and trustworthiness in which an honest man has the trust of his surroundings. The concept also entails dignity, integrity, virility and courage, as well as standing up for what one truly believes or sees even if it costs him certain price or sacrifice. It also means standing up for the weaker person, whether male or female. Within this definition of honor, the act of a group of dominant males in subjugating and condoning the murder of the weaker group of females is not in line with the true concept of honor. 
In fact, the consequences of honor crimes are physically and socially harmful due to the family collusion in these crimes that are essentially premeditated killings. Most of these crimes are quietly planned in the family or clan, where the tasks and roles are carefully shared and distributed among the participants. For instance, they falsely claim that the perpetrator is a minor or immature boy so that he gets a lighter sentence. Furthermore, Yasin (2018) reaffirms that most of the time everyone in the family agrees to fabricate the cause of death; in some cases, death certificates are issued stating natural causes of death in collusion with the entire circle of doctors, police and judiciary personnel involved. The perpetrators consider such act necessary to preserve the reputation of the family; therefore, enacting heavier punishment without addressing the social and psychological basis of the problem will only have a limited impact on the continuation and spread of these crimes.

More importantly, this act is not only seen as a dangerous and life-threatening act against women, but also a symbol of patriarchal subjugation which prevails in Islamic communities. Sharaf (2018) maintained that honor crime is therefore regarded as a social, cultural and religious practice that portrays Islam as a violent and patriarchal religion, when in fact Islam is a religion that organizes people's lives through many social issues so as to preserve the family as a strong entity which leads to a productive society and future generations. Based on this grim picture of the prevalence of honor crime in Jordan, it is timely to see how it is represented in Jordanian literature.

\section{Literature Review}

Shalan is a Jordanian author who was born and educated in Amman, Jordan. She gained her Ph.D in Modern Arabic Literature from the University of Jordan in 2006. Shalan is a contemporary prolific writer who has produced three novels, novellas, more than twenty anthologies of short stories, eight children's short stories, three academic books, memoirs and essays. In her works, Shalan explores several areas of romantic, human and children literature, criticisms, women, childhood, social justice, human rights, environment, political issues and other issues of human rights such as honor crime. Sowadiyya (2013, p. 12) asserts "Shalan is always revolting against the unconstitutional and unacceptable traditions and restrains practiced against women in her community". Shalan's novellas provide genuine reflections of the reality of the problem and its magnitude in Jordan. The way the writer addresses the issue of violence with all its forms reflects the continuous cycle of violence and the extent to which women are facing gender problems in their communities. Honor crime as a social illness is not an offshoot of Shalan's imaginative skills in prose writing, but rather a reality genuinely depicted in Tale of Tales.

In his 2014 study Our Honor is Our Blood in Sanaa Shalan's Tale of Tales, Ayman not only confirmed the fact that the social construction in Jordan is deeply tribal and patriarchal, but also that the familial construction encourages it. He further assumed that Shalan's depiction of the heroine, Amina reveals the harsh reality experienced by Jordanian women, who are viewed by their partners and the society as machines that have no opinion and must remain obedient or face dire consequences. Ayman also highlighted how the society waits for the women to err just 
so that they can denounce them and reaffirm the supposed fact that the cornerstone of corruption in society stems from the corruption of women. According to Ayman, the patriarchal atmosphere in the Jordanian culture is often supported by the misreading of the teachings of Islam which supposedly prioritizes males over females in all aspects of life.

As for academic scholarship of honor crime in fiction, several noteworthy studies have been selected for our literature review. In her 2013 study of how honor crime is depicted in Ibrahim Nasrallah's 2010 novel The Shame's Balcony, Karadsheh asserts that the novel is a clear reflection of the phenomenon of honor crime throughout Jordan. She reaffirms that Nasrallah does not hesitate to condemn honor crimes which is anything but honorable: "It is terrifying to read such a novel, as the victims of honor crimes fall around you, adding that before Nasrallah writes this novel, he has the opportunity to learn about more than fifty of honor crimes" (Karadsheh, 2010, p.2).

In his 2014 study on how honor crime is depicted in Rana Husseini's 2010 novel Murder in the Name of Honor, Ali offers a more detailed insight of the phenomenon in Jordan, reaffirming how honor crime is socially constructed as a result of the outdated social customs and traditions that prioritize males over females in all aspects. Despite the different contexts and pretexts behind the honor crimes presented in the said literary works, Shalan's Tale of Tales shares a sense of universal accord that honor crimes are socially driven and that Islam does not condone them. Against this and due to the nature of the honor crime as an act practiced in an Islamic context, the Islamic standpoint represented in the Holy Qur'an and Prophetic hadiths is factored as a conceptual framework in this paper to demonstrate that the roots and motives of this unhealthy act are socially embedded and have zero roots in Islam.

\section{Conceptual Framework}

Islam has been subjected to many misconceptions due to the fact that Muslims and non-Muslims alike think there is a gap between Islam and social and cultural concepts. In fact, several acts practiced by Muslims are derived from other cultural and social restrictions and complexities that are actually unrelated to Islam. Muslims in Arab countries such as Jordan mostly embrace a culture totally different from the nature, rules and teachings of Islam so much so that the western world believes that these are the actual key elements of the Islamic culture (SIGI, 2017).

From an Islamic perspective, honor crimes, like many backward practices, are the result of outdated social customs and traditions based on suspicions and obsessive concerns to uphold one's reputation. As Jumaa (2016: p .4) contends, "Most of the legal articles that condone honor crimes are taken from Egyptian law, which is primarily based on French law. However, there are those who still insist that honor crimes are related to the Islamic religion due to the non-application of the provisions of Islamic Sharia in daily life or ignorance of the teachings of the true religion." From an Islamic insight, honor crimes reflect the structural flaws in Arab and Islamic societies, where we must not give in to tribal and familial customs in a society dominated by Islam. Also, justice requires that we subject such matters to the standards of 
Islam, and that we are not honored by our customs that are contrary to the standards of our religion's beliefs, but rather by our concern to achieve equality between all parties in society, especially between men and women.

From an Islamic viewpoint, the rising number of cases of honor crimes in Arab Muslim countries does not mean it is an accepted act or a justified behavior by Islam. People must bear in mind that killings resulting from honor crimes are in total contradiction to Islamic teachings and are deemed baseless in Islam. First, the following Qur'anic verse elucidates the Islamic standpoint relating to the act of killing in general and honor crimes in particular. The Holy Qur'an says:

Whoever kills a believer intentionally, their reward will be Hell, to abide therein forever, and the wrath and the curse of Allah are upon them, and a dreadful penalty is prepared for them. (4:93)

In detail, the said Qur'anic verse asserts that nobody has the right to kill a Muslim believer. The intentional killing of a believer in Islam is considered one of the major sins of which the ultimate punishment is hellfire in the hereafter. In relation to the aforementioned Qur'anic verse, Ibn Kathir, a famous Muslim commentator (1365) says: "And whoever kills a believer intentionally. This Ayah carries a stern warning and promise for those who commit so grave a sin that it is mentioned along with Shirk in several verses of Allah's Book".

Second, prophetic hadiths, similarly, urge to preserve people's life and prohibit all acts of illegal killing of women. The prophetic hadith reported in the Two Sahihs cites the Messenger of Allah (PBUH) as saying: "If the world were to be destroyed, it would be of less importance to Allah than the killing of a Muslim". Abul-Hakam Al-Bajali also narrated: "I heard Abu Sa'eed Al-Khudri and Abu Hurairah mentioning from the Messenger of Allah (PBUH) that he said: 'If the inhabitants of the heavens and the inhabitants of the earth all took part in shedding the blood of a believer, then Allah would cast them (all) in the Fire". As well, it was narrated that 'Abdullah bin 'Amr had said: "Killing a believer is more grievous before Allah than the extinction of the whole world". These hadiths, along with the aforesaid Qur'anic hadiths verify that Islam strongly prohibits the acts of bloodshed of male and female Muslims. However, honor crimes' continual surge in tribal societies such as Jordan, in which Shalan's novella is set is still powered by social and tribal norms and habits related to the reputation and social stand of the family in the tribe. With that, honor crime is a practice in a few Muslim countries that needs to be eradicated disrespects women's lives. In this paper, however, the scope of honor crime is focused on in tribal and conservative societies such as Jordan in which Shalan's novella is set. In the following section, three noticeable standpoints of honor crime, namely: honor crime from social standpoint, honor crime from patriarchal standpoint, and honor crime from Islamic standpoint including Quranic verses and prophetic hadiths will be highlighted and analyzed within the scope of the aforementioned novella respectively.

\section{Textual Analysis}

\subsection{Honor Crime from Social Standpoint}


The Arab Muslim society is inflicted with the obsession of upholding their honor at all costs. This social ill is deeply rooted in tribal traditions that target women first whereby a lost honor can supposedly be restored by a father killing his daughter, a husband killing his wife, or a brother killing his sister. From a social perspective, women, their bodies and sexual desire and activity are not a private matter, but belong to the family, tribe and society, and virginity is the stamp of society on the honor of the girl, and the behavior of the wife outside the house is linked to the dignity of the man, not her dignity (SIGI, 2017). The Jordanian society is still governed by the authority of the tribe and the clan in relation to women. Despite the apparent manifestations of modernity, it is still dominated by the patriarchal system that evades the law in matters of honor, and this concept is specifically related to women. The following excerpt from the novella clearly portrays how the honor of a female is socially embedded rather than being related to her as an independent entity with rights, where Amina says:

When I was accused of tarnishing the honor and reputation of the family, all families and tribes that surrounded us, including Imam of the mosque and Fathi's relatives agreed that I must be punished so that I can be an example to others. (p.5)

In the Jordanian society, a Muslim woman lives in a state of torment under the pretext of preserving her honor, which she bears alone. Men are not punishable by the same penalties as women even if they have committed the same offense. This reflects the fragmentation of culture in the Jordanian society in which men are supposedly the ruler and rival of women. Such societal construct complicates the relationship between the sexes, making it impenetrable so much so that a healthy society based on love and brotherhood is unachievable. Instead, such society is built upon enmity and hatred between the males and females, and the men's weapon is the honor to subjugate the women.

From a social perspective, the structure of the Jordanian tribal society necessitates its men to commit honor crimes to defend the family's honor. A female who goes against the family's commands such as refusing to enter into a marriage planned by the family, requesting for divorce from an abusive husband, or wanting to marry a man from outside the tribe is punishable by death. The Imam's response to the killing of Amina showcases how such act is condoned by this society:

Do not be merciful with the sinner! Kill her; Kill her so as not to preserve our society from sinners like her. (p.7)

Fayez (2015) reaffirms that honor belongs to the family, tribe and society as a whole, adding that women are like olive trees whereby if its branch has decayed, it must be cut to keep the community stable, sound, healthy and clean. This affirmation is clearly portrayed in the following excerpt of the Imam's speech in the scene of the people gathering after Amina's killing.

Now, we purified our tribe from Amina and her heinous act which was a disgrace on all her family, her tribe and her society. Let's return to the mosque to pray Maghreb prayer. (p.8)

Without a doubt, the said extracts echo SIGI's (2017) notions concerning honor crime, where 
the act of honor crime is socially constructed, and a female can be simply killed for tarnishing the family's reputation.

\subsection{Honor Crime from Patriarchal Standpoint}

A Jordanian proverb says, "The male is the power of the family and society, and the female is a heavy burden that ends only with her marriage or death" (SIGI, 2017). This strange patriarchal society knows that it needs the womenfolk to continue their lineage, yet treats them badly and considers them a burden. Some conservative and patriarchal communities in the Arab and Muslim world like Jordan still believe that the female is a potential disgrace if the family does not discipline her well, and education should come with sharp scrutiny. The Jordanian society considers dishonor as a life-long shame.

As Issa (2018: p .6) contends "In patriarchal societies, a girl comes into life and understands that her brother is better than her and is more qualified for freedom. She sees with her own eyes the distinction between her and her male sibling who is always treated better and given more freedom in life". The following excerpt clearly portrays the gender inequality endured by the female character in the story, where Amina says:

Prior to his death, even if I did something wrong and it was simple, my father would come to punish me. (p. 4)

When we were young, my father and mother used to feed my brother, Fathi in a way better than me. (p.4)

Women in patriarchal societies die a gradual death, beginning from their birth. In other words, "the girl inherits from her mother the morals of misery and dependence on the male since her early childhood and sees her mother under the father's moral and physical control, beating and insulting silently for fear of divorce and return disappointed to the home of her family" (Khadr, 2016, p.7). There is no place for a divorced woman in a patriarchal society because she will be quickly branded as a disgrace and her movement will be constantly monitored and followed by doubt and suspicion. The following excerpt clearly portrays how a patriarchal society views females as a familial burden since childhood:

Since my early childhood, my father was always calling God to take my soul away before I grow up. He was saying may God take her away so that I get more relaxation. (p.4)

In the patriarchal society and based on the famous saying "Honor is a match that lights only once", the girl is keen on keeping her virginity as it is the most important value in the presentation of marriage. But in doing so, she is left feeling submissive and weak. Amina says:

I wish I had not been born here or would have traveled from here because my significance as a human lies only in my honor. I am valueless and no longer have rights. (p.5)

As Khadr (2016: p .2) reaffirms, "Due to the rigid patriarchal society, there is a rise in the 
number stories that tell the tragedies of girls who are victims of honor crimes in Jordan, as killings resultant from honor crimes have risen to unprecedented rates in Jordan with 53 percent in 2016 compared to last year". The first ten months of 2016 recorded 26 cases of murder of women, mostly under the pretext of honor crimes, provoking a wave of condemnation, anger and indignation at various levels amid calls for the punishment of the offender. "Many more honor killings occur in Jordan due to a lack of comprehensive reporting, the private nature of honor killings, and its widespread social acceptance" (Arnold, 2001, p. 1348). Additionally, it is asserted the fact that Jordanian laws concerning honor crime committers are not well-activated as required, leading to more victimizations and killings of women. Moreover, Karadsheh (2010) affirms that Jordan's abnormal number of cases of honor crimes serves as an indicator of inequality and injustice against females in a patriarchal society. Since the beginning of the novella, Amina says:

I am really saddened by the horrific stories of several women killed in other villages. (p.3).

Meanwhile, Devers and Bacon (2010) pointed out that in a patriarchal society as Jordan, an honor crime criminal is always on the loose and received no sentence in court due to the deeply rooted patriarchal traditions, values and norms that justify his illegal and immoral wrongdoing.

Dawaykat (2018) states that historically speaking, after reaching the age of puberty, many restrictions are placed on the Jordanian females by their fathers and brothers due to the rigid nature of the tribal society as can be seen in the case of Amina whose parents have already died. Amina is prevented from going to school because she has reached puberty and has to wear al-Malaya (Arabian dress) to cover her entire body. Amina says:

After being a mature girl, my brother, Fathi suddenly decided that I should wear a long black dress, cover my face and head with black veil. Later, I was banned from going shopping alone. (p. 11)

It is clear that Fathi's decision to deprive Amina of her rights to pursue education and other social activities such as shopping and visiting her friends and relatives is a response to the nature of a community with a patriarchal mentality. When Amina tells her brother that she wants to work, he gets angry and threatens to punish her if she brings the matter up again:

The moment I became mature, my brother refused to let me work in anyplace as it was disgraceful, adding that a fully closed room is a respected girl's place. (p.14)

Later on, Amina develops a romantic relationship with Ahmad, a teacher in a nearby school. She is fearful that her brother would find out and of the repercussions that may follow. She says:

Let's meet in a remote café. If Fathi sees us together, he will kill me in a shot. (p. 14)

Knowing that Amina may soon request for his approval of marriage, Fathi decides to deprive her of her inheritance and wealth. The tension increases after he fails to compel her to give away her money when she decides to marry, contradicting her brother's commands. Out of 
spite, Fathi fabricates a story that Amina has an illicit relationship with her lover, leading to her killing so as to purify the family's tarnished honor. After the deed is done, the Imam (Sheikh Ali) tells Fathi and the others:

May Allah damn Amina; she is a sinner. (p. 21)

As can be comprehended from the aforesaid extracts, Amina, like other victims of honor crimes, was deprived of her rights such as having an education, an independent identity, and inheritance from her parents. Her killing is a blatant demonstration of male domination with a patriarchal mentality that relies on violence as a method of disciplining powerless women. Fathi's honor crime was religiously blessed and glorified by the Imam which in turn Fathi was also welcomed by the general community as the Imam is highly regarded as a representation of the Islamic standpoint on the matter. With that, the third and last section will examine whether or not honor crime has roots in Islam.

\subsection{Honor Crime from Islamic Standpoint}

Islam is a religion where women are accorded the same rights as male believers. In surah Al-Ahzab (33:35), it is stated that:

Indeed, the Muslim men and Muslim women, the believing men and believing women, the obedient men and obedient women, the truthful men and truthful women, the patient men and patient women, the humble men and humble women, the charitable men and charitable women, the fasting men and fasting women, the men who guard their private parts and the women who do so, and the men who remember Allah often and the women who do so - for them Allah has prepared forgiveness and a great reward.

God does not differentiate the gender of His believers, only the depth of his or her faith, However, as Ayman, (2014, p. 2) says that "there are malicious norms and traditions inherited by some Arab societies, especially in the countryside where Islam has been accused, pointing out that Islam disowns these norms and traditions, which are not considered a crime in the right of the guilty woman but the whole humanity." The decision to direct the sentence and the conviction in these issues must be made by a competent Shari'a court because many misleadingly appoint themselves as judges and implementers of the provisions of justice, such as a husband to his wife or a son to his mother. This is not allowed by Islamic law in its rulings on honor crimes because chaos and violence against woman will prevail in societies, particularly in patriarchal societies. "Although violence against women is a global phenomenon, it is more prevalent and profound in third-world countries, especially those in which religious principles and patriarchal values are upheld as rules of governance" (SeyedehRobabeh Zabihzadeh, Ruzy Suliza Hashim, \& Gabriel Clement Chua Chen Wei (2015, p.1). Another fact asserted by Islam that it is not permissible for any person to kill the soul that God has forbidden except by the truth and whoever does so will receive sins. The Holy Qur'an says: 
And those who do not invoke with Allah another deity or kill the soul which Allah has forbidden [to be killed], except by right, and do not commit unlawful sexual intercourse. And whoever should do that will meet a penalty (25:68).

It must be stressed that Sharia considers such crimes as major crimes, whereby it is necessary to punish the perpetrator in order to prevent and protect the society from the encroachment of the implementation of provisions on crimes committed by individuals, noting that these crimes are against morality and the prevailing judicial laws. The highlighting of such crimes and follow-up work towards amending the laws dealing with such crimes is valuable and important, indicating that there is a duty to make the judges view such crimes in a fair and legal manner. However, the judges sometimes fail in imposing deterrent sanctions on the perpetrator of such crimes. Fathi boastfully says "Thanks to God. Laws in Jordan are always in favor of men. (p.22)

Since Fathi knows that he has a strong support by old figures and the Imam of the mosque, he decides to deprive Amina of her inheritance and wealth. Besides, the strong support powers Fathi to kill his sister, making a story that Amina has an illicit relationship with her lover, which is a tarnish that needs to be purified. The support Fathi received is gleaned from the speech of the Imam (Sheikh Ali) telling Fathi: "God bless you, man. This village has been cleansed from the evils and misdeeds caused by sinner, Amina”. (p.66)

Like most Arab and Islamic countries, the Jordanian Penal Law did not take its articles concerning honor crimes from Islamic law, but from European laws, especially French ones. The articles of the Jordanian Penal Law must be amended, since these articles constitute a supporting factor in committing of honor crimes and do not constitute a deterrent to perpetrators (Yasin, 2018, p.7). Hence, even the country's legal system fails to protect women from patriarchal abuse.

In light of the patriarchal norms, traditions and social heritage that view women as shameful, every woman of different culture is actually already sentenced to death. The perpetrator of honor killings is often valued and revered by his tribe or family, driving many of his peers to also commit an honor crime merely to emulate those criminals they perceive as heroes. Islam definitely does not condone honor crimes. For instance, in cases such as adultery, Islam requires four witnesses and set certain conditions for eloquent wisdom so as to not allow punishment by murder that is based on dishonesty, suspicion or anger. From an Islamic viewpoint, the four witnesses are required to give the same description of the scene of adultery and to swear that this is what they have seen, which is difficult and impossible. The intention is to prevent honor crimes and to maintain the reputation of the family involved. If there are only three witnesses, the given testimony will be rejected and the witnesses must be whipped. In the case of Amina, she never commits adultery, but her brother fabricates the story so that he can kill her and take her inheritance money. The following excerpt clearly portrays that the people around Amina including the Imam had made no efforts to ensure her a fair trial. The Imam says: 
Needless to investigate her case! She is totally guilty and Fathi is totally honest (p. 63).

The Holy Quran and the prophetic hadiths, however elucidated the Islamic standpoint about the acts of killings in general and honor crimes in particular. The Holy Qur'an says:

Whoever kills a believer intentionally, their reward will be Hell, to abide therein forever, and the wrath and the curse of Allah are upon them, and a dreadful penalty is prepared for them (4:93).

The aforementioned Qur'anic verse asserts that nobody has the right to kill a believer. When a believer is intentionally killed, the only repercussion for the killer is hell in the hereafter. Thus, the act of intentional killing in Islam is considered one of the major sins that a person can commit. In relation to the aforementioned Qur'anic verse, Ibn Kathir said: “And whoever kills a believer intentionally. This Ayah carries a stern warning and promise for those who commit so grave a sin that it is mentioned along with Shirk in several verses of Allah's Book".

In addition to the issue of the killing of a believer, Islam also discusses the sacredness of human life. Based on Islamic teachings, human life is thought to be the most sanctified of all things, and it is a Muslim's duty to preserve the life of another and ensure that a Muslim is not harmed, hurt or killed. The Holy Qur'an states:

On that account: We ordained for the Children of Israel that if anyone kills a person unless it be for murder or for spreading mischief in the land - it would be as if they killed all people. And if anyone saved a life, it would be as if they saved the life of all people. $(5: 32)$

The Holy Qur'an also states:

Because of that, we decreed upon the Children of Israel that whoever kills a soul unless for a soul or for corruption [done] in the land - it is as if he had slain mankind entirely. And whoever saves one - it is as if he had saved mankind entirely. And our messengers had certainly come to them with clear proofs. Then indeed many of them, [even] after that, throughout the land, were transgressors. (5:32)

The aforesaid Qur'anic verse verifies that honor crimes have no roots in Islam. More importantly, many prophetic hadiths condone the preservation of people's lives and prohibit all acts of killing including of women. It is reported in the two Sahihs that the Messenger of Allah (PBUH) had said: "If the world were to be destroyed, it would be of less importance to Allah than the killing of a Muslim". Abul-Hakam Al-Bajali also narrated: "I heard Abu Sa'eed Al-Khudri and Abu Hurairah mentioning from the Messenger of Allah (PBUH) that he said: 'If 
the inhabitants of the heavens and the inhabitants of the earth all took part in shedding the blood of a believer, then Allah would cast them (all) in the Fire". Additionally, it is narrated that 'Abdullah bin 'Amr had said: "Killing a believer is more grievous before Allah than the extinction of the whole world". These hadiths also verify that Islam strongly prohibits the acts of bloodshed of male and female Muslims as well.

As seen in the novella, killing women associated with 'honor crime' is a pervasive phenomenon in Jordan. In fact, the novella presents the disturbing situation where women's rights, opinions, persona and needs are not respected at all, leading her into a continuous cycle of killing in a cold blood. Shalan clearly sheds light on the fact that ordinary Jordanian women suffer from a patriarchal social context that exploits and kills them under the guise of honor crimes.

\section{Conclusion}

By presenting Amina as a protagonist who was raised in an unjust familial condition and later unlawfully killed by her merciless brother, Sanaa Shalan highlights to Muslim and non-Muslim readers the issue of honor crimes currently happening in many Arab Muslim countries including Jordan. The killing of the victimized, powerless, and submissive Amina by her brother is a clear example of the mislabeling associated with Islam.

Our reading of the novella centers on how Shalan makes great efforts to highlight one of the many misunderstandings that most Muslims and non-Muslims relate to Islam such as the killing of women through honor crimes. Without a doubt, Shalan's description of honor crime through the unlawful killing of Amina opens new venues for the readers to identify other misconceptions and acts supposedly related to Islam. Amina's killing by her brother with the blessings of the Imam and the entire society does not only show her disempowerment and victimization, but also provides an insight into the many negative acts and labels associated with Islam. Therefore, acts such as honor crimes must be read from other perspectives apart from a religious standpoint due to the fact that they are a result of social ills and complexities.

\section{References}

Al Ghammaz, L. Saifaldeen, Ruzy Suliza Hashim, \& Amrah Abdulmajid. (2020). Violence Against Women in Sanaa Shalan's Falling in the Sun. English Language and Literature Studies, 10(1), 53-64. http://dx.doi.org/10.5539/ells.v10n1p53

Ali, Abdullah Yousef. (1994). Holy Qur'an: Text and translation. Kuala Lumpur: Islamic Book Trust.

Ali, Ahmed. (2014). Honor Crime As a Social Aspect. Middle East Journal, 1, 19-31.

Arnold, Christine K. (2001). Are the Perpetrators of Honor Killings Getting Away with Murder? American. U. International Review Journal, 16(5), 1343-1409.

Ayman, Salem. (2014). Our Honor is Our Blood in Sanaa Shalan's Tale of Tales. Intellectual 
Discourse, 4, 25-35. 2020, Vol. 8, No. 2

Dawaykat, Ayman. (2018). Future of Violence Against Women in Jordan. Amman: Al Yazouri Publishing \& Distribution House.

Devers, Lindsey N \& Bacon, Sarah. (2010). Interpreting Honor Crimes: The Institutional Disregard Towards female victims of family violence in the Middle East. International Journal of Criminology and Sociological Theory, 3(1), 359-371.

Fanous, Kareem. (2018). The Qur'anic paradigm of honor crime: The Ulu al-Albab model. Intellectual Discourse, 2, 183-200.

Fayez, Ted. (2015). Honor Crime and Community. Arab World Journal, 1, 44-60.

Haddad, Abd. (2015). Honor Crime As a Social Aspect. Middle East Journal, 1, 11-32.

Hweija, Saher. (2016). Roots of Honor Killings. Intellectual Discourse, 2, 28-38.

Ibn Kathir, Ismail. (1365). Commentary of Ibn Kathir. Doha: The Center for Muslim Contribution to Civilization.

Issa, Maher.(2018). Physical and Psychological Violence Against Women and Girls in the Middle East. Arab Journal of Social Sciences, 1,1-9.

Jumaa, Mohammed. (2016). Honor Cime and Community. Arab World Journal, 2, 22-32.

Karadsheh, Tala. (2010). Honor Killings in Jordan: An Examination of Public Discourse. Virginia: The College of William and Mary.

Khadr, Asma. (2016). Honor crime: History and Roots. Dirasat Journal, 30, 17-27.

Shalan, Sanaa. (2007). Tale of Tales. Amman: Al Yazouri Publish and Distribution House.

Sharaf, Abdul Hafiz. (2018). Paradigm of Violence Against Women: Arab Model. Journal of Intellectual Discourse, 2, 18-31.

Sisterhood Is Global Institute. (SIGI, 2017). Incitement and Interference Push for the Implementation of More Crimes Under the Pretext of Honor. Retrieved from https://www.sigi-jordan.org/?p=2628_(March 27, 2020)

Sowadiyya, Ali. (2011). Women under violence. Dirasat Journal, 8, 12-25.

World Health Organization and Pan American Health Organization. (2012). Femicide: Understanding and Addressing Violence Against Women (WHO/ RHR/12.38), 1-8. Geneva: World Health Organization. Retrieved from https://apps.who.int/iris/bitstream/handle/10665/77421/WHO_RHR_12.38_eng.pdf?sequence =1\&isAllowed=y_(March 28, 2020)

Zabihzadeh, Seyedehrobabeh, Ruzy Suliza Hashim, \& Gabriel Clement Chua Chen Wei. (2015). Domestic Violence Against Women in Atiq Rahimi's The Patience Stone. GEMA Online Journal of Language Studies, 15(3), 51-66. 


\section{ABOUT THE AUTHOR}

Saif AL-Deen AL Ghammaz has a Master's degree in English Literature from Philadelphia University in Jordan. He is currently a Ph.D. candidate in English Literature (specializing in postcolonial literature) at Universiti Kebangsaan Malaysia. His research interests focus on Muslim and Arab women writing and Middle Eastern writing in both Arabic and English.

Ruzy Suliza Hashim (Ph.D.) is a Professor of Literature at the School of Language Studies \& Linguistics, Universiti Kebangsaan Malaysia. She obtained her BA with Honors from the University of Otago, MA in Sociology of Literature from Essex University, and Ph.D. (Literature) from the University of Otago.

Amrah Abdul Majid (Ph.D.) is a Senior Lecturer at the School of Language Studies \& Linguistics, Universiti Kebangsaan Malaysia. She obtained her BA from the International Islamic University Malaysia (IIUM), PG Diploma (English Literature) from Monash University, and Ph.D. (Arts) from Monash University.

\section{Copyright Disclaimer}

Copyright for this article is retained by the author(s), with first publication rights granted to the journal.

This is an open-access article distributed under the terms and conditions of the Creative Commons Attribution license (http://creativecommons.org/licenses/by/3.0/). 